\title{
Epistemological Models in Understanding Cultural and Civilizational Specificity
}

\author{
${ }^{* 1}$ Victor P. Rimskiy, ${ }^{2}$ Galina N. Kalinina, ${ }^{3}$ Tamara I. Lipich, ${ }^{4}$ Inna M. Nevleva, \\ ${ }^{5}$ Vladimir A. Noskov, ${ }^{6}$ Sergey V. Reznik \\ ${ }^{1}$ Belgorod State University, Pobedy St., 85, Belgorod, 308015 Russia
}

Email: rimskiy@bsu.edu.ru

\section{Received: 21st October 2017 Accepted: 16th November 2017, Published: 31st December 2017}

\begin{abstract}
The article proposes a methodology for linking the formation-evolutionary, cultural-civilizational, ethnological, and cultural-anthropological models in understanding the changes of complicated sociocultural systems. Ethnic being is the most powerful energy source of individual and collective mythogenesis. In today's difficult conditions, there is a need to involve cultural and anthropological epistemological models to the socio-humanitarian study, in the centre of which there is a "living person" - a concrete historical individual. This approach opens the possibility of an adequate study of the specifics of the cultural and civilizational development of Russia at all stages of its socio-cultural changes. Dedicated epistemological models allow to adequately study the specifics of the cultural and civilizational development of Russia, updated in line with the next wave of modernization of the country.
\end{abstract}

Keywords: Formation-Evolutionary Model, Culturalcivilizational and Ethnological Models, Historicism, Cultural-anthropological Methodology, A Living Person, Human Being, Philosophical-Anthropological Method, Cultural Archetype.

\section{Introduction}

The formational evolutionary epistemological model (methodology) is associated, as a rule, with the names of the Marxism classics. And, indeed, we see this methodological, class scheme of knowledge of the mankind history already in the Manifesto of the Communist Party, the first representative Marxist publication [1, p. 424-425]. It gets its finished, classical look from V.I. Linin: "As Darwin put an end to the view of species of animals and plants as unrelated, random, "created by God" and unchangeable, and placed biology on a completely scientific basis for the first time, establishing the variability of species and continuity between them, so did Marx putting an end to the view of society as a mechanical aggregate of individuals, allowing all kinds of changes according to the will of the authorities (or, still, by the will of society and the government), arising and changing by chance, and put sociology on a scientific basis by establishing the natural economic formation as a combination of these production relations and determining that the development of such formations was a natural historical process for the first time" [2, p. 137, 139].
Lenin's comparison of Marx with Darwin was meaningless: the style of thinking in the humanities of the XIX century was wholly shaped by the concepts and categories of natural science: "formation" and "revolution", "social organism" and "political organism", "social revolution" and "class" - all these concepts were originally used in the sciences of nature, loaded with a specific natural-science sense. The main thing in the formation-evolutionary model was the search for stable social and historical facts, exploring which one could give a scientific explanation to the mankind history, could turn the history into a strict scientific discipline in the nature of science. And until very recent years, this meant nothing more than the transfer of the principles of determinism to historical development, the study of the history of society as a coherent chain of causes and effects, a view of history as a regular, natural process.

The formational evolutionary paradigm did not contradict the cultural and civilizational epistemological schemes and models at all. The classical versions of cultural and civilizational epistemology are represented by the unique work of the Russian thinker N.Ya. Danilevsky "Russia and Europe" [3], as well as directly or indirectly to this book by the ascending works of $O$. Spengler "The Decline of Europe" [4] and A. Toynbee "Study of History" [5]. N.Ya. Danilevsky made also an attempt to supplement the cultural and civilizational methodology with the ethnological model.

At the turn of the XIX and XX centuries in Europe and Russia, the philosophy and social sciences introduce an ethnological dimension in the comprehension of history, but they use rather vague "metaphysical" terms and concepts: for example, the Russian "people" ("народность") and "people's spirit" ("народныйдух") or German "völkisch" ("Völkerpsychologie", etc.) and "Deutschtum", "Zeitgeist". It was a specific "völkisch discourse" [6]. However, there were also quite scientific works in which not only metaphysical "people's spirit", but also "ethnicity" were studied at the same time (including in the Soviet period), as G.G. Shpet pointed out, conceptualizing own "ethnic psychology", which had more to do with the "social anthropology" and "ethnology": he directly spoke about this scientific discipline [7, p. 486, 494]. He criticized the substantionalist (essentialist) versions in the understanding of socio-historical, civilizational and ethnic processes long before the domestic and western constructivists. We could put the works of S.M. Shirokogorov [8], who was also a pioneer in the 
development of the theory of ethnos, in the row with him.

\section{Methodology}

We proceed from the fact that all the above-mentioned epistemological models are fully matched within the framework of the philosophical-anthropological method, within which the deep foundations of human existence are studied, which has both natural, social, and communicative, and cultural-symbolic dimensions, where primary cultural archetypes, schematism of the ideal in the forms of consciousness and unconscious are formed [for more details see: $9 ; 10]$. Therefore, the existence of man in a certain political, economic or cultural environment, and in the "plasma" of ethnoses as the natural-historical, "borderline" entities, plays an important role in the cognition of human existence.

\section{Main Part}

The emphasis in the formation-evolutionary model on the description of past and present social forms embodied in the sustainable formations - instruments of labor or productive forces, property and state institutions, family, science achievements - actually brought the social sciences closer to the ideal of "rigor and accuracy", already achieved by the natural science at first glance, since it was possible to establish certain criteria for recurrence and typicality in the history of the most diverse peoples and countries, to classify social orders, to decompose the "types of states" on the shelves. And, most importantly, since we brought the criteria of determinism, rigor, repeatability into the humanities, then we could predict the future with greater or lesser success. But all the "scientific and futuristic predictions" were failed in the last decades.

The cultural-civilizational epistemological model, trying to replace the formal paradigm in the last twenty years, has not eliminated its main "sin" - the naturalhistorical schematism. Many domestic authors, applying the concepts of "culture" and "civilization" to the interpretation of concrete-historical facts, seriously believe that their own texts reflect the "cultural and historical ontology." K. Popper rightly reproached almost all the theories of cultural and historical process in the sin of historicism without exception [11], since we can speak only about the ideal types in the Weberian understanding that help us isolate certain cultural and civilizational types and build some concepts only on the basis of systemic analogies, system regularities, indifferent to the content (and ideological) characteristics of empirical, concretehistorical systems, the study of which is a lot of special sciences.

This rectilinear historicism is especially evident in the constructions of Russian researchers, for whom the "Russian cultural and civilizational type" is only a product of the conflict of "catch-up modernization" of Russia and its allegedly cultural, patriarchal, communal and authoritarian-etatist heritage in all its transformations right up to the post-Soviet realities. But any, not only Russian, form-building cultural and civilizational processes cannot be explained by the simple opposition of "traditionalism - modernization" or the recognition of the Russian type of "marginal civilization". It was also hard to explain the addition of domestic cultural and civilizational paradigm and "national specifics": did the European traditionalism or the European modernization not appear in the form of "French" or "English" specificity?

Is it possible to harmonize both established epistemological models - the formation-evolutionary and the cultural-civilizational paradigms? How is the principle of discreteness of history, pluralism of cultures and civilizations, and the principle of continuity, evolutionary succession and progressiveness in the mankind development combined? Are the "material factors" - productive forces, production relations, the level of technology development, the social conditions of people's life, etc. - the defining springs of socio-historical movement? Or do the cultural and "spiritual" factors - science, religion, art, morality, ways of spiritual production and communication, etc. - dominate in the historical perspective over the economic and political foundations of historical existence? After all, there are numerous examples where the countries that are very techno-economically advanced in their development have suddenly rested on some mystical "walls" and "dams", stopped their rapid, demonstrative movement, and sometimes perished, went into historical oblivion. L.N. Gumilev [12] once suggested looking at the dilemma arising from the opposition of two cognitive models (he called the formation-evolutionary model "world-historical"), by analogy with quantum physics, the principle of indeterminacy, according to which light was neither a wave, nor a particle, but both of them; so it was possible to set the value of two variables only by separating them, but not simultaneously. Within the ethnological model, he introduced a third "variable" - ethnogenesis and ethnic history, which, in his opinion, was almost not conjugated with the world historical and culturalcivilizational history, because the ethnos was supposedly an entirely natural phenomenon implemented only in the "social body" of history and culture.

According to the epistemological point of view, both the formational-evolutionary and the culturalcivilizational methods are realistic, universalist models, proceeding from the primacy of the whole and universal over the private and individual, abstract society over the living person, "law" over the "concrete situation", they are oriented toward comprehension of world history in its integral characteristics, on evolution and continuity, they are forced to turn to the most stable, inherited (from generation to generation, from people to people) products of cultural human activity. First of all, there are the instruments of labor, the means of production ("material culture") - they are most easily documented by a professional historian as evidence of continuity. However, it has already been observed that such schemes of world history grew on 
the basis of European history and suffered obvious Eurocentrism, did not take into account either the ethnic or cultural-anthropological diversity of mankind. And yet, if one follows the logic of being a simple person in the history comprehension, one cannot reject the fact of man's material, subject-labor activity as the basic for the cultural-civilizational process as well. A human joins with nature namely in labor: the system "nature-man" is the original for the ethnic life of people. L.N. Gumilev is right, when he defends the specificity of ethnic life, the ethnos uniqueness, which cannot be reduced to either culture or society.

Human is originally born and perceives a certain ethnic and cultural-civilizational environment. Even a London or Parisian inhabitant of slums and dumps in the middle of the XIX century, before becoming a "proletarian", learned both language and ways of communication, as well as national self-awareness. And the whole history of pre-capitalist societies was all the more measured by the ethno-cultural existence of man, and only then - to a small extent - by the economic and political existence. Classes and class relations in their pure form are the product of European capitalist (industrial) history. There were other stratification mechanisms in the depths of antiquity: there we find ethnosocial groups of people and religious-ethnic communities, corporative-class and ethno-corporative formations, dominating over the behavior and consciousness of a single individual. The person in his daily activities is most often guided not by "class" consciousness or considerations of utility (and not even by "higher" ideals and values), but by drives and passions, the origin of which is not always clear to us. However, this does not mean that the nature of these passions and drives is purely biological, and our own "passionarity" (L.N. Gumilev) depends on the degree of confusion of "genes" of different "ethnic origin" in us.

The main opponent of the theory of L.N. Gumilev and the ideological theorist on behalf of the current Russian science is V.A. Tishkov, who heads the Institute of Ethnology and Anthropology of the Russian Academy of Sciences. Philosophical meaning of the ideas of V.A. Tishkov can be reconstructed according to the monograph "Requiem for Ethnicity: the Studies on Socio-Cultural Anthropology"[13] and articles in the "New Philosophical Encyclopedia" [14].V.A. Tishkov writes that the concept of "ethnos" (and more procedural "ethnicity") does not have strict categorical rationalization. He unambiguously opposes the primordial (essentialist or substantionalist) methodology in understanding the ethnos.

Indeed, the elusiveness and processuality, mythological symbolism and powerful social-symbolic constructivism are present in the real life of ethnoses. But does this mean that they do not have any ontological (not to be confused with the substantial - it is not the same) basis? It turns out that V.A. Tishkov has such: it is "a community based on cultural selfidentification with respect to other communities" [14, p. 483]. However, the assertion of culture (cultural identity) as the "basis" of ethnoses and ethnicity is the same "essentialism", as in the case of Marxism or "cosmological" theory of ethnogenesis of L.N. Gumilev. Only here some abstract "culture" is consedered as a "substance". In fact, the ethnicity dissolves in culture, although V.A. Tishkov gives the most trivial interpretations of culture and cultural identity.

It is interesting that V.A. Tishkov in his interpretation of the nation, on the one hand, seems to proceed from its interpretation as a "civil nation", and, on the other hand, criticizing the substantionalist and constructivist approach (close to him in the understanding of ethnicity) for some "ontologism" (read: philosophy) in the nation's problem for their actual merging, takes a stand of relativism. But then it is not clear: what is the difference between the concept of "civil nation" (in our case the "Russian nation"), proposed by V.A. Tishkov, as an "official ethnologist", for the wide use of Russian political elites from equally close Marxist interpretations of the "nation", "national policy", "the right of nations to self-determination" that underlay the Soviet practice of constructing "new nations" within the "new historical community of the Soviet people"? The latter, as we see, went west.

Ethnic being itself is the most powerful energy source of mythogenesis, individual and collective, and generates transformed forms of myth, primarily political, in the situation of the crisis of ethno-cultural identity [for more details see: 15, 16, 17]. At the same time, some myths are productive, projective in nature, playing the role of engine of the cultural and civilizational changes, while others are destructive, generating both ethno-cultural and socio-political "chimeras" and political and ideological temptations, leading the elites and individuals, the real history subjects, to a dead end. The collapse of the USSR was initiated not so much by any "intrigues of the West", by social conflicts and economic turmoil, as by the reckless policies of the party elite headed by M.S. Gorbachev, who sharpened the sharp competition of ethnic elites at all levels within the party and the intelligentsia, which caused national contradictions and the corresponding national (nationalist) mythology as a powerful destructive factor in the collapse of the union state and the Soviet cultural and civilizational system. The ethnic mode of being and cultural diversity is increasingly breaking into the socio-cultural dynamics of postmodernity. This is, first of all, the migration of numerous peoples from the backward regions of the South and East into the developed countries of the West and the United States. This scenario included also the ethnic and cultural conflict in the geopolitical space of the USSR and post-Soviet Russia. But after the exaltation of multiculturalism and multiethnicity as new liberal values of the coming global civilization, there suddenly appeared a sobering under the cold shower of "new terrorism". It became indisputable that the factor of "new ethnicity" determined not only the geopolitical field of mankind, but the everyday life of each person as well. Apparently, we can talk not only about the "crisis of personal identity", 
but about the crises of collective (group) and personal ethnoidentity, associated with "revolutionary" or "stagnant" processes in the sociocultural and ethnocultural world dynamics [for more details, see:15].

Here we come to the need to involve cultural and anthropological epistemological models in the social and humanitarian research. In our opinion, the point of support and the junction of all the lines and cycles of the historical "flow" is human: not an abstract person of philosophers, not a "subject", not a "class person" of politicians, but a living person, a particular historical individual in which it is possible to find ethnic quirks in the form of self-awareness and behavioral stereotype, a certain cultural skill and forms of activity learned in the socialization process, and the level of life and lifestyle, rooted in the existing economic system, the production mode and the "structures of everyday life" (F. Braudel), and the class interests, not always meeting the actual position of a person in a certain socio-political stratum.

\section{Summary}

An inseparable chain of successive phenomenological metamorphoses begins in the ontological depths of the life of a living person: "consciousness - unconscious", "individual consciousness - collective", "culture civilization "б "material production - spiritual production", etc. - all of them are the continuous inter conversions, creating concrete historical phenomena of the era, unique, distinct Cosmos of human existence. But these links of concrete historical metamorphosis do not manifest themselves as abstractions - they are always exposed, have a face, reflect the life of real people, social and ethnic groups, are clothed in the historical garments of cultures and civilizations, live in real spaces of politics, economics, everyday life.

\section{Conclusions}

Thus, based on the analysis of the formationevolutionary, cultural-civilizational, ethnological and cultural-anthropological models in understanding the dynamics of complex socio-cultural systems, we come to the conclusion that there is a need to involve cultural-anthropological epistemological models, in the center of which there is a "living person" - a concrete historical individual - in today's challenging conditions. This approach opens the possibility of an adequate study of the specifics of cultural and civilizational development of Russia at all stages of its socio-cultural dynamics.

\section{References}

[1] Marx K. and Engels F., 1955. Manifesto of the Communist Party // Marx K. and Engels F. Compositions. 2nd Edition. V. 4. M. P. 419-459.

[2] Lenin V.I., 1967. Who are the "Friends of People" and How do they Fight the Social Democrats? // Lenin V.I. Complete Set of Works. 5th Edition. V. 1. M. P. 125-346.

[3] DanilevskyN.Ya., 1991. Russia and Europe. M. Shpengler O., 1993. The Decline of Europe. V. 1. Novosibirsk.

[4] Toynbee A.J., 1991. History Comprehension. M.

Bourdieu P., 2003. Political Ontology of Martin Heidegger. M.

[5] ShpetG.G., 1989. Introduction to the Ethnic Psychology // ShpetG.G. Compositions. M.

[6] Shyrokogorov S.M., 2012. Ethnos: Study of the Basic Principles of Changing Ethnic and Ethnographic Phenomena. M.

[7] Rimsky V.P., 1997. Demons at the Crossroad: Cultural and Historical Image of Totalitarianism. Belgorod.

[8] [Rimsky V.P. et al.], 2017. The establishing Discourse of Mikhail Petrov: Intelligent Thinker in the Design of Cultural Capital; Edited by V.P. Rimsky. M. Popper K., 1993. Poverty of Historicism. M.

[9] Gumilev L.N., 1990. Ethnogenesis and Biosphere of the Earth. L.

[10] Tishkov V.A., 2003. Requiem for Ethnicity: Research on Socio-Cultural Anthropology. M.

[11] Tishkov V.A., 2010. Ethnicity // New Philosophical Encyclopedia: In 4 Volumes. M. V. IV. P. 482-484.

[12] Rimsky V.P., 2011. Deferred Crises of Ethnoidentity in Modern Russia: Theoretical Stereotypes and Political Myths // Scientific Statements of Belgorod State University. Series "Philosophy. Sociology. Law". No. 20 (115). Issue 18. Belgorod. P. 359-367.

[13] Rimsky V.P., Kalinina G.N., 2012. Self-Surrender of Science and Transformed Forms of Knowledge // Scientific Statements of Belgorod State University. Series "Philosophy. Sociology. Law". No. 20 (139). Issue 22. Belgorod. P. 28-39.

[14] Rimsky V.P., Rimskaya O.N., 2012. Modern Mythology and Subcultural Religions // Scientific statements of Belgorod State University. Series "Philosophy. Sociology. Law". No. 8 (128). Issue 20. Belgorod. P. 67-74. 